\title{
Mario Bunge (1919-2020): Conjoining Philosophy of Science and Scientific Philosophy
}

\author{
Martin Mahner ${ }^{1}$
}

Accepted: 11 January 2021 / Published online: 21 March 2021

(c) The Author(s), under exclusive licence to Springer Nature B.V. part of Springer Nature 2021

\begin{abstract}
The leitmotif of Mario Bunge's work was that the philosophy of science should be informed by a comprehensive scientific philosophy, and vice versa; with both firmly rooted in realism and materialism. Now Bunge left such a big oeuvre, comprising more than 70 books and hundreds of articles, that it is impossible to review it in its entirety. In addition to biographical remarks, this obituary will therefore restrict itself to some select issues of his philosophy: his scientific metaphysics, his philosophy of physics, his concept of mechanismic explanation, his philosophy of social science and technology, and his approach to the demarcation problem. The final section will explore why Bunge, despite the extent and depth of his work, has not achieved a more prominent status in the philosophical community.
\end{abstract}

Keywords Mario Bunge $\cdot$ Metaphysics · Ontology $\cdot$ Materialism $\cdot$ Realism $\cdot$ Philosophy of science $\cdot$ Philosophy of physics $\cdot$ Philosophy of technology $\cdot$ Philosophy of social science Philosophy of mathematics $\cdot$ Scientific philosophy $\cdot$ Scientific explanation $\cdot$ Scientific theories $\cdot$ Mechanism $\cdot$ Demarcation

\section{From Physics to Philosophy}

Mario Augusto Bunge was born in Buenos Aires, Argentina, on September 21, 1919, and died in Montreal, Canada, on February 24, 2020. His father, Augusto Bunge, was a descendant of Swedish-German immigrants who came to Argentina in the early nineteenth century. The elder Bunge was a physician and in 1916, under the banner of the new Socialist Party, got elected to congress. Bunge's mother, Marie Müser, was a nurse, who emigrated from Germany to Argentina in 1913 after having realized that her home country was preparing for war.

Mario grew up in a large property with a garden and an orchard on the outskirts of Buenos Aires. From an early age he was exposed to the intellectual circle of his father's friends, who visited the Bunges frequently. He was encouraged to read books in their original language, German, French, Italian-whence Bunge's ability to communicate in several

Martin Mahner

mahner@gwup.org

1 Zentrum für Wissenschaft und Kritisches Denken, GWUP e.V., 64380 Rossdorf, Germany 
languages. High school, by contrast, turned out to be rather boring due to the incompetence of most of his teachers. In his memoirs, Bunge describes it as "jail-like", and himself as a mediocre pupil (Bunge 2016). At the time of his adolescence, Argentina was ruled by a military dictatorship, and its educational system was still firmly in the hands of the Catholic church. Thus, Bunge suffered from two repressive authorities ruling the public life of his youth. Consequently, he compensated for the deficiencies of the educational institutions by self-learning from the substantial resources of his father's library as well as from the libraries of his family's friends.

At the age of 18 Bunge was equally attracted to physics, psychology, and philosophy as possible university subjects (Bunge 2016). He was inspired by Bertrand Russell's Problems of Philosophy, Sidney Hook's From Hegel to Marx, and Lenin's Materialism and Empirio-Criticism. However, he abandoned his wish to study philosophy after attending some lectures at the local university because the neo-Hegelianism and Bergsonian intuitionism he encountered there conflicted with his pro-science stance. He also realized that in his country there was no psychology to speak of. That left physics, but his father told him that he would not be able to make a living as a physicist. For this reason he started to study chemistry but gave up after the first year because he found it boring. The appeal of physics and philosophy was overwhelming. Subsequently, Bunge became a student of physics at the National University of La Plata.

When starting his studies Bunge felt that he should repay society for financing his education. Thus he founded a school of vocational and humanistic studies for adult workers, in particular union activists: the Universidad Obrera Argentina (UOA). The little office Bunge had rented for this purpose was soon raided by the fascists, so that he had to find another place. Despite continuing difficulties with government entities and various political factions, the school eventually grew to about 1000 students and 60 teachers. After 6 years, it was ransacked and closed down by the Peronist police.

In that same year of 1943 Bunge was introduced to the physicist Guido Beck, a former disciple of Werner Heisenberg. With him he started his scientific apprenticeship, as he called it. Early on he succeeded in publishing several scientific papers in high profile journals such as Physical Review (Bunge 1944) and Nature (Bunge 1945). In 1951 he completed his doctoral dissertation on the kinematics of the relativistic electron, which was published only in 1960 (Bunge 1960). In his memoirs Bunge writes that, contrary to its misleading title, his thesis proved that there was actually no kinematics of the relativistic electron, because quantum mechanics does not compute trajectories and velocities, which is why it is not a mechanical theory (Bunge 2016, 78). He also remarks that his doctorate in physics was of no immediate professional use because he refused to be a member of the Peronist party. After his work with David Bohm in São Paulo, Bunge devoted more time to his equal intellectual love: philosophy.

Ever since high school Bunge kept reading books on philosophy. Although he lacked a coherent outlook back then, his scientific stance made him realize that, with respect to his interests, many of the philosophies he had encountered were useless. So, as early as 1944 - at age 25 and with the help of a circle of friends - Bunge decided to launch a philosophical journal to tackle problems he deemed important. It was called Minerva and lasted for a year before it ran out of submissions and money (Bunge 2016; Ortiz 2019).

As a physics student Bunge was impressed by the scientifico-philosophical work of Arthur Eddington and James Jeans. Yet soon he came to the conclusion that their philosophies of physics were mistaken because they advanced Kantian idealism and Platonism, respectively. He was similarly unimpressed by what he learned in the various philosophy classes he attended during his time as a student of physics. Still, due to his committed 
autodidactic work, the basis of his future philosophy slowly emerged. Thus, in the first half of the 1950s Bunge wrote several papers on problems in natural philosophy, such as on chance (Bunge 1951), phenomenalism vs. realism (Bunge 1954), and philosophical questions of quantum mechanics (Bunge 1955, 1956a, b). In 1991, Bunge's 1956 paper A Survey of the Interpretations of Quantum Mechanics made it into the list of the most memorable articles from the American Journal of Physics since its inception in 1933 (Romer 1991).

During the second half of the 1950s Bunge's career as both a scientist and philosopher took off. In 1956 he became full professor of theoretical physics at the universities of Buenos Aires (until 1958) and La Plata (until 1959), in 1957 full professor of philosophy at the university of Buenos Aires-a position he held until 1962, when a military coup brought Bunge and his (second) wife Marta to emigrate after all. This period was marked most notably by his book Causality: The Place of the Causal Principle in Modern Science, published in 1959 by Harvard University Press at the recommendation of W.V.O. Quine (Bunge 1959). This book put Bunge on the international philosophical map (Matthews 2019). It argued, contrary to the Humean view of logical empiricism, that science requires causality to be a category of real-world determination. Although Humeans were not happy with it, the book was quite a success and translated into many languages. Nowadays we see a revival of causal realism, although Bunge's early stand is almost always overlooked (Ingthorsson 2019).

In the first half of the 1960s Bunge held several visiting professorships in the USA, at the universities of Pennsylvania, Texas, and Delaware as well as at Temple University. Three more books appeared during that time, among them a festschrift for Karl Popper (Bunge 1962; 1963; 1964b). An Alexander-von-Humboldt fellowship in Freiburg (Germany) during the years 1964-1966 prepared his way to a life-long professorship at McGill University in Montreal. In 1966 Bunge completed his book project Foundations of Physics (Bunge 1967a), in which he axiomatized and formalized several physical theories, while his wife Marta obtained her doctorate in mathematics. Not wishing to return to the USA on account of the Vietnam war, and in view of a post-doctoral fellowship for Marta at the Mathematics Department of McGill University in Canada, Mario passed up an offer from Yale University and instead wrote to the chairman of McGill's philosophy department, the Renaissance scholar Raymond Klibansky, inquiring about possibilities for himself there (Bunge 2016).

To Bunge's surprise, Klibansky not only knew his work rather well, but he even knew about his early short-lived journal Minerva. He thus invited Bunge to introduce himself to the relevant university authorities - a serendipity which resulted in a full professorship, and the Bunges' move to Montreal in November 1966. At the end of her post-doctoral fellowship, Marta was appointed assistant professor of mathematics at McGill in 1969, promoted to associate professor in 1977 and full professor in 1985. As of 2003 she is professor emerita. In 1981 Mario Bunge obtained the chair "Frothingham Professor of Logic and Metaphysics", which he held until his retirement in 2009—at age 90! During his long career he was awarded four honorary professorships and 22 honorary doctorates by universities all over the world (Bunge 2018a).

After his McGill arrival, Bunge's work became even more prolific than before. In 1967 his Scientific Research appeared (Bunge 1967b), a two-volume introduction to the philosophy and methodology of science. A Philosophy of Physics followed in 1973 (Bunge 1973a). Between 1974 and 1989 Bunge published his opus magnum, the 8-volume Treatise on Basic Philosophy. The first two volumes were dedicated to semantics (Bunge 1974a; 1974b). Volumes 3 and 4 offered a formalized ontological theory, which Bunge considered 
as constituting the materialist metaphysical basis of science (Bunge 1977a; 1979). Volumes 5 and 6 tackled general epistemology and methodology (Bunge 1983a, b). The twopart 7th volume applied his philosophy of science to the major scientific disciplines, such as physics, biology, social science, and technology (Bunge 1985a, b). Volume 8 completed the Treatise with an axiomatic approach to ethics (Bunge 1989)—something that is quite unusual in this field.

As if this workload were not enough, 1980 saw the publication of The Mind-Body Problem (Bunge 1980), followed by Scientific Materialism (Bunge 1981), as well as Philosophy of Psychology (Bunge and Ardila 1987). At the end of the 1980s Bunge's focus shifted to the social sciences, which bore fruit in his Finding Philosophy in Social Science (Bunge 1996a) and Social Science Under Debate (Bunge 1998a), followed eventually by Political Philosophy (Bunge 2009).

Compared to the extent of his analyses of physics, psychology (including the mind-body problem) and social science, Bunge's work in the philosophy of biology was rather limited. He wrote about the concept of life, systematics and the species problem, teleology, and evolution (Bunge 1985b; Mahner 2005). This limitation proved to be a good opportunity for some coworker to expand on these rudiments (Mahner and Bunge 1997).

With the exception of his Political Philosophy mentioned previously and Medical Philosophy (Bunge 2013), Bunge's twenty-first century work was no longer focused on expanding his philosophical system. Most of his books written after 2000 consisted in attempts at summarizing or revisiting certain topics and aspects of his philosophy and tailoring them to different audiences (Bunge 2003a; 2006; 2010; 2017; 2018a; Bunge and Mahner 2004). For a quick autobiographical overview of his most important contributions to philosophy and to the philosophy of science see Bunge (2003c); for a selection of Bunge's articles forming an outline of his philosophy, see Mahner (2001).

Considering the sheer volume of Bunge's oeuvre (see Silberstein 2019 for the most recent bibliography), this epitaph will have to restrict itself to some select aspects.

\section{Metaphysics: Materialism and Nomological Essentialism}

In my view, one of Bunge's most important contributions to philosophy was his metaphysics. His aim was to build a metaphysical system that is at once exact and scientific or science-based, respectively (Bunge 1971; 1977a; 1979; 1981). In 1971 Bunge founded the Society for Exact Philosophy. On the book cover of the proceedings of the founding congress (Bunge 1973b), he wrote: "We believe that even metaphysics, notoriously riotous, can be subjected to the control of logic and mathematics". Indeed, formal ontology has now become a standard field in analytic metaphysics. Likewise, the notion of scientific metaphysics has been revived (Kistler 2020)—regrettably oblivious of Bunge's programmatic sketch of 1971 (Bunge 1971), not to mention his full-fledged version of a scientific metaphysics (1977a; 1979). ${ }^{1}$

A short description of Bunge's metaphysics would be that it is an endurantist, neoAristotelian, ${ }^{2}$ and neo-essentialist, materialist substance ontology. In a rather classical way Bunge constructed the notion of a material thing from the notions of substance and

\footnotetext{
1 Bunge used "metaphysics" and "ontology" synonymously.

2 Needless to say: without any idealist or teleological burden.
} 
property. Indeed, there are no bare substances (or individuals) and no free-floating properties: there are only propertied individuals, which he calls things. A universal property of all things is the possession of energy (in the physical sense) and thus their ability to undergo change. Because the values of all the properties of a thing constitute the state of the given thing (at a certain time), any change is a change of state. A change of state is an event, and a succession of such changes a process. There are no changes (events or processes) without changing things, in particular no processes in themselves, apart or prior to things as assumed by process ontologies. Bunge further characterized a cause as an event in some thing $x$ that produces a change of state of another thing $y$. All this can be represented by using the state space approach common in science and engineering.

Bunge's construal defines materiality in terms of the property of energy-cumchangeability, and so is independent of the property of possessing mass. A photon is just as material as a rock, and so is a vacuum field. Nor does Bunge's ontological theory use the concept of spacetime to define material objects, i.e., things. He adopted a relational view of spacetime, according to which, in essence, time is the result of the change of things rather than conversely, and space the result of "separated" things, rather than conversely. In any case, space and time are derived concepts in his 1977 ontology. More recently, however, Bunge regarded the empirical confirmation of the existence of gravitational waves as a compelling reason to consider spacetime as a material thing, too (Bunge 2018b). Modifying his ontological theory accordingly, will now be left to others.

An important concept of Bunge's ontology is the notion of a nomological state space. It focuses on the essential or lawful properties of things. Lawful properties are properties of a thing that are invariantly or covariantly connected to each other. Such properties restrict the conceivable state space of any thing to its really possible state space. In this way Bunge defined lawfulness as an ontological category-as the properties or property complexes scientific law statements (are supposed to) refer to. The lawful properties of a thing - shorter: its laws - constitute its essence, and it is this essence that determines the kind (or type) of the given thing. This is why Bunge called his view nomological essentialism. What distinguishes real possibility - the only possibility of interest to science-from logical possibility - a favorite of philosophers - is exactly the ontic lawfulness of things and their changes. These considerations explain, by the way, why Bunge regarded musings about logical possibilities in possible worlds as rather useless (Bunge 2006), and why he had no use for modal logics as tools for metaphysics (Bunge 1977a). Both neo-Aristotelian metaphysics and neo-essentialism, according to which laws are in rebus, have nowadays been revived or reinvented, respectively (see, e.g., Ellis 2002; Tahko 2012; Austin 2017).

Things are either simple, such as electrons, or complex, such as molecules or societies. As most things are complex, the concept of a system was central to Bunge's metaphysics (Bunge 1979). He modeled a system as a triple $\langle C, S, E\rangle$, where $C$ is the system's composition (the set of parts it is composed of), $S$ its structure (the set of relations among its parts), and $E$ its environment (the set of things outside of the system). As there is no system without cohesion, the important subset of relations within $S$ comprises what Bunge called "binding relations", that is, such that make a difference to the states of the components involved. The same holds for the relations between the system or its components and the items in the system's environment: some make a difference to the system in question, others do not (such as typical spatiotemporal relations). Obviously, this leads to a nested sequence of systems: what is a system at one level may be a subsystem of a higher-level system (Bunge 1979; Blitz 1992). 
Systems have properties their components lack, trivially being structured in a certain way. Bunge went the traditional way of calling such properties emergent. However, he emphasized that, as emergence is an ontological concept, "emergent" should not be defined in epistemological terms such as "a property that cannot explained or predicted from the knowledge of the components". It is irrelevant to the ontological status of a qualitative novelty whether or not we can explain it reductively: qualitative novelty does not go away when explained. Therefore, the common distinction between strong (or irreducible) emergence and weak emergence (emergence simpliciter) was of no interest to Bunge's ontology.

The same held for the concept of supervenience, which Bunge considered to be a form of property parallelism (Mahner and Bunge 1997) —at least in its early version of Kim (1978). For him, "supervenience" was no alternative to "emergence" because the latter involves a one-sided and lawful property dependence. Moreover, in formal definitions of "supervenience" properties are treated in a logical rather than ontological way. According to Bunge's ontological theory of properties (Bunge 1977a), real things have neither negative nor disjunctive properties. Therefore they need to be formalized in terms of inf-semilattices, not in terms of Boolean algebra. This is also a reason for Bunge's insistence on distinguishing real properties from predicates, the latter being conceptual representations of properties. Some predicates, however, such as the negative and disjunctive ones, do not represent real properties. Similarly, it was important to him to distinguish laws as properties of real things from (universal) law statements as their (true or false) conceptualizations.

Finally, Bunge kept using the term "materialism" for his metaphysics. He disliked the word "physicalism" because to him it smacked of radical reductionism. He insisted that while higher-level systems do also possess physical properties, their emergent higher-level properties are beyond the explanatory competence of physics - which is why we have higher-level sciences such as chemistry, biology and social science. Distinguishing strong from moderate reductionism, he maintained that not even chemistry is strongly reducible to physics (Bunge 1982a; 1983b; 1985b).

\section{Abstract Objects, Existence as a Property, and Semantics}

Speaking of representations and conceptualizations: a materialist philosophy will have to address the problem of the existence of abstract objects, that is, the objects of mathematics as well as other objects that are not found "out there" but only in our minds. Obviously, a Platonist option is not available to materialists as they cannot admit the reality of immaterial entities. Thus, Bunge opted for a fictionalist or constructivist answer (Bunge 1981; 1985a): Mathematical objects are just as fictional as the objects of literature, such as Othello or Superman.

Now, fictionalism has a problem with the apparent objectivity of mathematical entities as opposed to the arbitrariness of fantastic entities. This objectivity is the reason that many a philosopher of mathematics prefers Platonism over fictionalism. Platonism, however, is hard to reconcile with the naturalistic approach of analytic philosophy. Therefore some naturalists have proposed a structuralist approach, according to which the structure of the world possesses mathematical properties (see, e.g., Kanitscheider 2013). In Bunge's ontology only particulars are material or real existents, whereas some mathematical objects are universals. In addition, he maintained that mathematics is ontologically neutral and that there is a gap between mathematics and reality in that the whole of mathematics is richer 
than the fraction of it that can be applied to scientific theories describing the world (Bunge 2001).

In any case, as abstract objects are fictions or constructs that exist only in the brains of thinking organisms, Bunge held that ontological realists and materialists should distinguish two different kinds of existence. He held that pace Kant "exists" is a real property and should thus be construed as a predicate, and that pace Quine the existential quantifier is insufficient to account for the concept of "existence", let alone to distinguish real from fictional or conceptual existence (Bunge 1981). In other words, $\exists$ formalizes the logical concept "some", not the ontological concept of existence ("there is"): it is a particularizer only. So, whenever the context involves ontological considerations, its formalization must include different predicates for real and conceptual existence: $\mathrm{E}_{\mathrm{R}}$ and $\mathrm{E}_{\mathrm{C}}$.

For example, how did Bunge formalize a sentence like "Centaurs do not exist really but only in Greek mythology"? Let C represent "is a centaur" and $\mathrm{M}$ the set of characters in Greek mythology (as a specification of the conceptual context): $\forall x\left(C x \rightarrow\left(E_{M} x \& \neg E_{R} x\right)\right.$ ). And the sentence "Some of the centaurs in Greek mythology are wise" would be formalized as: $\exists x\left(C x \& W x \& E_{M} x\right)$ (Bunge 1981). Again, such a construal is needed only if the ontological status of the corresponding objects is at issue. After all, in both science and philosophy there are contexts in which the reality of the objects of a given theory or context is unknown or controversial. Does God really exist or is he/she/it just a fiction? Does the aether exist? Is the Higgs-Boson real or is the standard theory that predicts its existence false, whence it would exist only as a fictional object? Neither in science nor in philosophy does mere reference entail real existence.

This approach has implications for Bunge's semantics (Bunge 1974a; 1974b). Mainstream semantics would say that "being a centaur" is a non-referring predicate because there are no centaurs; more precisely, because they do not exist really. Bunge rejected this view. "Being a centaur" refers to (is about) centaurs as fictional objects, but the extension of the predicate is empty, where "extension" is defined as the collection of objects that actually (really) happen to possess the property denoted by the predicate in question.

Again, these considerations are motivated by Bunge's scientific outlook. Scientific theories may contain referents that do not actually exist, such as the luminiferous aether, and they may attribute properties to really existing objects that do not actually possess them, such as when vital forces were attributed to developing organisms. And in some cases scientific theories are wrongly believed to refer to certain entities, such as the observer in quantum theory. To account for such cases, Bunge distinguished the reference class of a theory from its extension. Accordingly, he had no use for the so-called causal theories of reference, which may apply in some ordinary language contexts ("This is an elephant"), but not to many scientific theories referring to unobservables, such as neutrinos. In fact he developed a comprehensive formal semantics for the purpose of analyzing scientific theories (Bunge 1974a; 1974b).

As for the concept of truth, Bunge maintained that there is not the one notion of truth that applies to all contexts. Rather, we need to distinguish at least three different concepts (Bunge 2003b). First, there is factual truth as correspondence, which is needed in science and often in everyday life. Second, there is formal truth, such as in logic and mathematics, which is a concept of coherence, rather than correspondence or convention. Third, there is fictional truth, which is conventional, occurring in works of literature, for example. That Oedipus killed his father and married his mother are not facts in the realist sense, but just arbitrary conventions or stipulations concerning fictional entities. In other words, such statements are true only in the context of the given story as a fiction. 
As mentioned in Sect. 2, in Bunge's ontology there are neither negative nor disjunctive properties. Accordingly, there are no negative and disjunctive facts, so that propositions speaking of such cannot be correspondence-true. This is no problem in science because scientific theories state what is the case. What is not the case is at most a logical consequence without factual counterpart. In particular law statements are to be formulated positively. This is why Bunge rejected Popper's view of law statements as prohibitions (Bunge 1983b; Popper 1969).

Another problem of correspondence-truth is this: how can a proposition, which is an abstract or fictional object, correspond to a fact "out there"? Bunge naturalized correspondence in that he construed propositions as equivalence classes of brain processes. That is, a proposition exists only when some brain undergoes a process that consists in thinking it. However different such processes may be in different individuals, they are all equivalent concerning their content: they consist in thinking a certain proposition. So, what corresponds to a real fact out there is first of all the equally real brain fact (=thought) in some individual brain. Thus correspondence-truth is primarily a fact-fact correspondence and only secondarily (or vicariously) a proposition-fact correspondence (Bunge 1983b; 2003a). And such correspondence may be only partial, which is why we need a concept of partial or approximate truth. In particular scientific theories as systems of propositions will hardly ever correspond in toto to the facts they refer to (Bunge 1974b; 1983b; 2003a). Moreover, Bunge considered scientific theories as symbolic representations of facts: they neither mirror or picture facts nor are they isomorphic to them.

\section{Defending Realist Interpretations of Scientific Theories}

Axiomatizing and formalizing scientific theories as well as analyzing their reference class was Bunge's way of showing that scientific theories have a strictly realist or, as he called it, factual content. That is to say, apart from some neurobiological and psychological theories dealing with human perception, scientific theories refer neither to observations or phenomena in the sense of phenomenalism nor to empirical operations in the sense of operationalism (Bunge 1985a). This was clearly an antipositivist endeavor. While Bunge appreciated the neopositivists' love for exactness and rigor, he rejected their antimetaphysical and antirealist - that is, phenomenalist, empiricist, and instrumentalist—stance. And the same held for its operationalist offspring, which was quite popular among physicists during Bunge's heyday.

Unsurprisingly, one of the most interesting fields for philosophers of science and philosophizing physicists remains quantum physics. The spectrum of views ranges from genuine and important insights concerning ontology and the philosophy of nature to outright quantum esotericism (Stenger 1995; Hobson 2019). In this spectrum, antirealist positions still go strong (Schlosshauer et al. 2013), so that Bunge's efforts to defend realist views and interpretations of quantum theory are as topical today as they were in the 1950s, when he started to tackle such questions (Bunge 1956a). These efforts culminated in his axiomatization of quantum theory (Bunge 1967a, c).

The title of his contribution to the book Quantum Theory and Reality that he edited at that time, aptly exemplifies his approach: A Ghost-Free Axiomatization of Quantum Mechanics (Bunge 1967c). "Ghost-free" means that the axiomatization is thoroughly physical, that is, it contains "no psychological concepts such as 'observer', 'mind', 'subjective probability', 'expectation', 'uncertainty' or 'finding', and no fictions such as 'ideal 
measurement' and extra 'hidden variables' with no effects" (Bunge 1967a, 274). More recent realist axiomatizations (Perez Bergliaffa et al. 1993) and interpretations (Hobson 2019) sustain this view. Another result of his axiomatization was that quantum theory works perfectly well with ordinary logic: there is no need for any quantum logics (Bunge 1985a).

An example of Bunge's exact and realist approach is the interpretation of Heisenberg's inequality $\Delta \mathrm{p} \cdot \Delta \mathrm{x} \geq \mathrm{h} / 4 \pi$, which states that the product of the dispersions in the values of the momentum, hence the velocity, and the position of a quantum object is at least $h / 4 \pi$. As Bunge pointed out, this inequality is not a principle: it is actually a theorem that follows from the postulates and definitions of quantum theory (Bunge 1977b; 1985a). And it is not an "uncertainty relation" either, as it is not about human cognition. Quantum objects do have more or less fuzzy or blurry-valued properties: the more sharply they are localized, the more blurry their velocities; conversely, the sharper their velocities, the fuzzier their positions. Thus, any limit to human cognition is due to the blurry properties of these nonclassical objects, not to any inherent limit of our cognitive apparatus or to perturbations of measuring instruments. In other words, Heisenberg's theorem describes objective fuzziness: what is not there in reality cannot be known by us.

Acknowledging that, unlike the referents of classical physics, quantum things objectively possess fuzzy properties, Bunge considered it a bad idea to define "realism" in terms of classical physics as Einstein, Podolsky and Rosen did in their famous paper from 1935 (Einstein et al. 1935). As he kept pointing out, the development of quantum theory does not entail that (both metaphysical and epistemological) realism has to be given up but instead what he called "classicism", according to which all physical objects are characterized by sharp properties and locality or non-separability, respectively (Bunge 1985a; 2012; Stöckler 1990).

As a strong supporter of theory axiomatization, Bunge adopted a statement view of scientific theories. This view has been dismissed as the "received view" of scientific theories (e.g. by Suppe 1972), which supposedly has been superseded by structuralist and semantic approaches (see, e.g., McKinsey et al. 1953; Suppes 1957; Stegmüller 1976; Sneed 1979; Suppe 1989; Thompson 1989). Bunge regarded these alternatives as defective because they conflate mathematical formalisms and mathematical models with scientific theories (Bunge 1973a; 1983a; Mahner and Bunge 1997). In his view, an uninterpreted mathematical formalism is just a piece of mathematics, and its supposed "intended interpretation" is clearly extra-theoretical. Bunge maintained that a factual interpretation must be an explicit part of any scientific theory (as opposed to a purely mathematical theory), hence of every axiomatization. He also held that mathematical model theory has nothing to do with scientific models. The specification or interpretation, respectively, of an abstract mathematical theory is an entirely intra-mathematical affair, whereas endowing a mathematical theory with (supposedly) real referents is a completely different matter (Bunge 1983a; 1985a; see also Truesdell 1984; Weingartner 1990). For a summary of Bunge's contributions to the philosophy of physics see Romero (2019).

\section{Mechanismic Explanation}

In 1967 Bunge published a two-volume introduction to the philosophy and methodology of science, entitled Scientific Research (Bunge 1967b). It is an early summary of his views on this subject, parts of which he refined and improved later on in volumes 5 and 6 of his 
Treatise (Bunge 1983a, b). As one would expect from such a book, it contains a chapter on the notions of scientific theory and explanation. According to Bunge, theories come in different levels of depth—a view already proposed in Bunge (1964a). At the superficial end, there are black box or phenomenological theories, which are "close to the phenomena" in that they deal, for instance, with some more or less observable inputs and outputs. Think of the chemical formula of photosynthesis $6 \mathrm{H}_{2} \mathrm{O}+6 \mathrm{CO}_{2} \rightarrow 6 \mathrm{O}_{2}+\mathrm{C}_{6} \mathrm{H}_{12} \mathrm{O}_{6}$. A deeper theory, by contrast, is supposed to tell us something about the very process, the mechanism, that transforms the input into the output. In Bunge (1967b) he called such deeper theories "representational" because they represent the modus operandi of their referents; in Bunge (1983b) he used the more obvious name "mechanismic theories". Bunge chose the neologism "mechanismic" over the common term "mechanistic", because mechanisms need not be mechanical in the strict sense of "mechanics".

This distinction carries over to scientific explanations. For Bunge, the covering law or deductive nomological account of explanation, as mere logical subsumption, may be adequate for phenomenological theories. It does not though really answer how- and why-questions. In Scientific Research he infelicitously called explanations uncovering the modus operandi of the facts involved "interpretive explanations" because they involve the interpretation of an observable variable in terms of unobservables or "hypothetical constructs" (Bunge 1967b, vol. 2, p. 26f). In volume 6 of his Treatise he chose the better name "mechanismic explanation" (Bunge 1983b). In his later work Bunge's focus was the application of mechanismic explanations to the social sciences (Bunge 1997).

Today, explanations in terms of mechanisms or "causal processes" have made their way into the mainstream of the philosophy of science (see, e.g., Machamer et al. 2000; Craver and Tabery 2015). However, many authors do not restrict mechanisms to processes but also consider the structures of systems, or the structured system itself, as mechanisms, such as with the mechanism of a watch. This is a view that Bunge considered mistaken. Now, the philosophers who are credited as the fathers of the mechanismic approach to scientific explanation are Peter Railton (1978) and Wesley Salmon (1984), not Mario Bunge (Glennan 2002). But the basic idea was foreshadowed already in Bunge (1957), and its essence can be found in Bunge (1964a; 1967b) and in more detail in Bunge (1983b). ${ }^{3}$ Indeed, Bunge goes unmentioned in both Salmon's review Four Decades of Scientific Explanation (Salmon 1989) and the entry Mechanisms in Science of the Stanford Encyclopedia of Philosophy (Craver and Tabery 2015). ${ }^{4}$

\section{Bunge's Philosophy of Social Science}

Next to physics, no other scientific field captured Bunge's interest as much as the social sciences (Bunge 1996a; 1997; 1998a; Pickel 2004). As the son of a socialist congressman and growing up in a country with recurring right-wing dictatorships, early on Bunge acquired an acute appreciation for liberty, social justice, and political activism. In the case of physics, Bunge's philosophical motivation was metaphysical and epistemological. In the case of the social sciences his motivational basis was, in addition to the aforementioned, ethics as well as social and political philosophy.

\footnotetext{
3 At the end of his 1997 paper on mechanisms and explanation, Bunge summarizes the development of his ideas on mechanismic explanation.

${ }^{4}$ Bunge's absence in such overviews is only rarely noted, e.g. by Johansson (2019).
} 
Understanding scientifically how social systems work constitutes the background of what he called sociotechnology: the science-based design, repair or maintenance of social systems and processes. In Bunge's words: sociotechnologists "are expected to recommend the most efficient ways of setting up, maintaining, reforming, or dismantling social systems, as well as of triggering, quickening, regulating, or slowing down social processes. In particular, they are expected to cure social ills" (Bunge 1996a, 205). Examples of sociotechnologies: action theory, normative economics, law, and management (Bunge 1998a). The goals for sociotechnological endeavors are provided by ethical and socio-philosophical considerations, while scientific knowledge helps to implement them optimally.

Bunge's first goal was to show that the scientific study of the social requires distinguishing the correct levels of analysis. Traditionally there are two antithetic ontological and methodological approaches towards the social: individualism and holism. As persons or individuals are the actors in society, it is tempting to believe that knowledge of individuals, their motivations, decisions, and actions is all that needs to be known in order to understand anything social. The extreme example is Margaret Thatcher's (in)famous claim that there is not even such a thing as society (Bunge 1996a, 243). Bunge described individualism as being on the side of individual liberty, economic self-interest, and as having its focus on moral rights rather than duties. At the other end is holism (or collectivism), according to which society precedes the individual and shapes the latter's thoughts and actions. Its focus is on duties in that the individual ought to strive to be a useful member of society. Holism need not end up in totalitarianism, where the People, the Nation, or the Church is all that matters, but, so warned Bunge, it is always in danger of doing so.

As an alternative to these poles, Bunge proposed his own version of systemism, which is an application of his systems ontology to the level of the social. Obviously, a social system is characterized by the composition, structure, and environment triple mentioned in Sect. 2. In the simplest case, the composition is of course constituted by individuals, the relevant structure comprises the interpersonal relations of the individuals, and the environment consists of the persons, social systems and resources that are not part of the given system but are relevant to it.

Social systems exist at different levels of complexity, from street gangs to transnational corporations. And they have emergent properties such as, trivially, social structure, and, nontrivially, inflation rate or political stability. The composition of more complex systems, such as economic ones, will not just include human beings but also artifacts, such as tools and machines, domestic animals, etc. (Bunge 1998a, b). Very complex social systems are of course whole societies. Any society is composed of social subsystems of four kinds: biological or kinship systems; economic systems engaging in production and exchange; political systems managing the social activities in the given society; and cultural systems such as choirs, sports clubs and schools (Bunge 1996a).

Bunge rejected not only the holist idea that society acts upon its members, but also the individualist claim that society is nonexistent or at least irrelevant. His systemic answer was that "interaction between two social systems is an individual-individual affair, where each individual acts on behalf of the system he represents. The members of a social system can act severally upon a single individual, and the behavior of each individual is determined by the place he holds in society, as well as by his genetic endowment, experience, and expectations. And every social change is a change of the structure of a society, hence a change at both the social and individual levels" (Bunge 1996a, 267f.).

Accordingly, explanations in social science will need to take into account at least two levels of organization and thus two directions of reduction: downward and upward, or 
micro and macro. Thus, there are micro- and macroreductive explanations of social facts, depending on the aims of the given explanation. Bunge gives this example (1997, 453):

$\begin{array}{cccc}\text { Macro level } & \text { Income increase } & \rightarrow & \text { Fertility decrease } \\ \text { Micro level } & \begin{array}{l}\text { Old age security and } \\ \text { improved education }\end{array} & \rightarrow & \text { Family planning }\end{array}$

This also exemplifies a mechanismic explanation as it unearths some process unfolding in or among social systems. The purely phenomenological description income increase $\rightarrow$ fertility decrease concerns only one level: the level of a macrosocial process. It becomes a mechanismic explanation by considering the micro-level and integrating the relevant factors on both the micro and macro level.

As a critic of individualism Bunge was also a staunch critic of rational choice theoryif regarded as an explanatory "theory of everything" in the social sciences (Bunge 1995; 1996a; 1999). To him the idea that social science is reducible to the study of the utilitymaximizing behavior of individuals, was an inappropriately strong version of reductionism. This was not to deny that rational decisions do play a role in human action, but a criticism of (a) the (mis)use of the adjective "rational" in the sense of "selfish" or "self-interested" or "utility maximizing", and (b) the excessive explanatory ambitions of the various rational choice theories.

For the purpose of amusement, as well as to show that apparent exactness should not be counted in favor of rational choice theory, Bunge proposed an axiomatized and formalized "futility theory", which was supposed to be just as explanatorily ambitious yet empirically shaky as its utility rival (Bunge 1996a, 397ff). Thirty years earlier Bunge had already formulated a "theory of phantoms" to warn against mistaking mathematization for scientificity (Bunge 1967b, vol. I).

\section{Bunge and the Problem of Demarcation}

The use of fake theories to illustrate the question of what makes a theory scientific takes us to another aspect of Bunge's work: the attempt to distinguish genuine science from pseudoscience. Now this is not a unique feature of his work, as a number of other philosophers of science, such as Popper and Lakatos, did the same before. However, Bunge's approach, though ultimately too strict, proved to be particularly comprehensive and fruitful (Bunge 1982b; 1983b; Mahner 2007; Fernandez-Beanato 2020).

The foundation of Bunge's approach is the detailed characterization of an epistemic field. An epistemic field is a group of people including their theories and practices, aiming at gaining knowledge of some sort. Whether that aim is eventually accomplished or not is immaterial. This presupposes a Popperian concept of knowledge where truth is not a necessary attribute of "knowledge", though of course a desired one. Bunge analyzed an epistemic field $\mathscr{E}$, for any given time, as an ordered set or, more precisely, a ten-tuple $\mathscr{E}=$ $<C, S, D, G, F, B, P, K, A, M>$, where $C$ represents the inquiring community; $S$ the society hosting $C ; D$ the domain or universe of discourse of the members of $C$; $G$ the general outlook or philosophical background consisting of a metaphysics, epistemology, and methodology; $F$ the formal background, if any; $B$ the specific background consisting of knowledge 
items borrowed from other fields; $P$ the problematics or collection of problems concerning the members of $D$ or other components of $\mathscr{E} ; K$ the fund of knowledge, that is, the collection of knowledge items previously obtained by the members of $C ; A$ the aims-cognitive, practical, or moral - of the members of $C$; and finally $M$-the methodics or collection of methods or techniques used by the members of $C$ in their study of the members of $D$.

An epistemic field is scientific iff, for example, $C$ is a research community (rather than a belief community); $S$ permits free research (e.g., neither the state nor the church dictate which results are permissible); $D$ deals only with concrete or material entities; $G$ consists of a realist and naturalist metaphysics as well as a realist epistemology and a methodology encompassing a number of well-known logical, semantical, methodological as well as attitudinal and moral values, such as consistency, clarity, parsimony, testability, explanatory power, critical thinking, universalism, etc.; $K$ is a growing collection of items (rather than a stagnant one); $B$ is nonempty, that is, a scientific field is connected to neighboring fields.

This rather complex characterization, which cannot be further explicated here, combines descriptive and normative criteria. While the normative criteria are decisive for the science-pseudoscience distinction, the descriptive criteria render possible the consideration of psychological and sociological aspects of demarcation. In addition, some normative features of science are realized by its social organization: for example, self-correcting mechanisms are implemented by the scientific community rather than individual scientists, who, after all, may be just as prone to human bias as anyone else.

Bunge believed that his characterization of science provided a list of individually necessary and jointly sufficient criteria of demarcation (Bunge 1982b). However, this belief was too strict. Demarcation won't work with any set of necessary and sufficient criteria because the realm of pseudoscience is too variegated. A realistic demarcation will have to restrict itself to disjunctive or cluster approaches and therefore remain somewhat fuzzy-yet nonetheless useful (Mahner 2007; 2013; Dawes 2018; Fernandez-Beanato 2020).

Bunge also applied his analysis of epistemic fields to religion, which he regarded as incompatible with a scientific outlook (Bunge 1983b; Mahner and Bunge 1996; Mahner 2014; 2018). Considering religion an illusion, he had no deeper interest in the philosophy of religion though. More important to him was the criticism of approaches or entire fields that he considered intra-academic pseudosciences or pseudohumanities, respectively, such as certain post-modern relativist and antirealist developments in the sociology of science (Bunge 1991; 1992; 1993; 1996b).

\section{Bunge's Philosophy of Technology}

In his 1976 paper The Philosophical Richness of Technology (Bunge 1977c), Bunge gave a long list of features and problems of technology, ranging from metaphysics to ethics. Examples: What is the ontological status of artifacts? What role, if any, does truth play in technology as compared to basic science? What is the difference between technological rules and scientific laws? Is technology for evil purposes itself evil?

Bunge's analysis of epistemic fields allowed him to distinguish technology from science in many respects (Bunge 1983b; 1985b). The major differences concern the coordinates $P$ and $A$ of the ten-tuple mentioned in the preceding section: the problematics and aims of technology are practical and action-oriented rather than cognitive. And the technological community $C$ is less free and open than the scientific community because patents and industrial secrecy limit the circulation of technological knowledge. Finally, unlike basic 
science, technology is to be analyzed by an eleven-tuple. That is, a coordinate $V$ is to be added: the external value system of the given technology. Whereas (basic) science has only internal values such as logical and methodological ones, technologists evaluate natural and artificial things as to their practical utility and efficiency.

In tune with this analysis, Bunge characterized applied science as an epistemic field that tries to solve cognitive problems with ultimately practical concerns in mind. That is, unlike the basic scientist, an applied scientist does not just come up with a certain finding $x$ for purely cognitive purposes, but in addition with the suggestion that $x$ may be helpful to produce a useful item $y$ or to prevent some undesirable item $z$. If researchers take the step from knowing to doing, that is, if they actually design or produce some useful item, they are technologists. Thus, Bunge regarded technology as the design, realization, operation, or maintenance of things or processes of practical value with the help of knowledge gained in basic or applied science.

The latter condition is important because Bunge restricted the use of "technology" only to science-based endeavors. If only craftsmanship, however primitive or excellent, or prescientific empirical knowledge is involved, he used the term technics. He warned against conflating technological research with the industrial production of items designed by technologists (Bunge 1988). He also pointed out that these conceptual distinctions do not entail that basic scientists, applied scientists and technologists need always be different persons: of course any given scientist may work at the same time or at different times during his or her career as a basic or applied scientist and a technologist, depending on the nature of the given research. An example is certainly with medicine: a (multi)discipline ranging from basic bioscience through bio- and medical technology to medical practice (Bunge 2013).

This example shows that Bunge's conception of technology is not restricted to physical and chemical technology, such as engineering and pharmaceutics. In tune with his metaphysics distinguishing several ontic levels of systems, there is technology also at the biological and the social level. Recall the notion of sociotechnology introduced in Sect. 6. Although there is no mental level in Bunge's ontology because the mental is not a thing of its own, it is still useful to refer to fields like psychiatry, commercial psychology, and education as psychotechnologies (Bunge 1988).

Bunge (1998b) ventured to suggest that, provided they are based on scientific knowledge, even some normative philosophical areas qualify as technologies in his broad sense, such as moral philosophy, praxeology, and methodology. And just as there are pseudosciences, there are of course pseudotechnologies, such as homeopathy or the various forms of ,water vitalizinge ${ }^{\text {ee }}$ In fact, many fields usually featured as pseudosciences are in fact pseudotechnologies like much of alternative medicine (Bunge 1983b; Mahner 2007).

\section{Bunge as a Philosophical Maverick}

Considering the sheer volume and broad scope of Bunge's oeuvre, he may be seen-and is in fact seen at least by his fans-as a philosophical giant of the twentieth century on into the 21 st. However, this appreciation stands in stark contrast to his actual impact on mainstream philosophy. While Bunge has quite a good standing in Latin American philosophy as well as among natural scientists and some older philosophers of science, his huge oeuvre is barely quoted by contemporary mainstream philosophers. A review of his life and work that intends to be more objective than a mere eulogy needs to address this puzzling situation (see also Plenge 2020). 
Although Bunge was an original and individualistic thinker from the start, he was an active part of the philosophical community during the 1960s and the early 1970s. However, roughly from the mid-1970s on, we may diagnose the beginning of his retreat from this community, which resulted in a maverick status by the end of the 1980s. This isolation was the result not just of his own philosophical development but also of a deliberate rejection by large parts of this community that treated him as some sort of philosophical pariah.

Indeed, Bunge was very well aware of the fact that he kept brushing against the philosophical grain when, in 1974, he ended the general preface to his 8-volume Treatise with the prescient motto: „Do your own thing. Your reward will be doing it, your punishment having done it". What were the reasons for this curious development? Let me venture to suggest four (inter-relating) reasons for this bungeophobia:

1. Bunge was ahead of his time concerning certain philosophical issues.

2. Quite a bit of Bunge's work was considered old-fashioned by his contemporaries.

3. He built a comprehensive philosophical system - and got caught up in it.

4. Certain personality traits—in particular one that I shall call furor philosophicus-did not exactly help Bunge make or keep friends in the philosophical community.

In the preceding sections it was mentioned several times that certain philosophical views - for a time thoroughly rejected-have more recently undergone a renaissance. Now they are positions worthy of discussion, or even part of the mainstream. These examples were causal realism (Sect. 1), the notion of a scientific and neo-Aristotelian metaphysics including a realist or ontic view of laws (Sect. 2), and mechanismic explanation (Sect. 5). The debates about these issues could have started earlier if Bunge's contributions had been acknowledged at the time of their publication.

Bunge's interest in demarcation (Sect. 7) certainly appeared old-fashioned in the light of "the demise of the demarcation problem" declared by Laudan (1983) in a paper of great influence in the philosophy of science. Though never really dead, the insight into the need for demarcation also re-emerged in recent times (see, e.g., Pigliucci and Boudry 2013). Bunge's work was unabashedly realist (see Sect. 4 as well as Cordero 2019). Although it was of course of the critical variety, trying to distinguish fact from fiction, it did require some courage in a situation where quite a number of philosophers including philosophers of science considered some form of anti-realism as the compelling result of deeper thought. In particular, Bunge insisted that especially quantum theory did not provide any good arguments against realism. In tune with his realist stance, Bunge kept defending a statement view of scientific theories while the majority turned towards non-statements views (Sect. 4). He even defended his own version of scientism, attempting to free this much-maligned concept from its derogative connotation (Bunge 2003b; 2015).

More, still, Bunge did something that is not exactly fashionable in analytic philosophy: he spent most of his time and effort building a comprehensive philosophical system. He believed that philosophy of science should not be done in a fragmentary way, that is, by analyzing isolated problems just by means of logic and general methodology. Instead, Bunge's grand view was that good philosophy of science not only requires a solid background in the science in question: it should also be based on a coherent philosophical system comprising at least semantics, metaphysics, and epistemology. Only thus can we avoid, for example, mistakes and misinterpretations encountered in the philosophy of science, such as in the philosophy of quantum physics (see Sect. 4). This philosophical system needs to be even more comprehensive to tackle social science, which requires that ethics, 
social and political philosophy as well as praxeology be added to that edifice (see Sect. 6 as well as Bunge 1989; 1996a; 1998a).

However, building a huge philosophical system came at a price. First, this work consumed most of Bunge's time. As a result, he more or less stopped participating in the topical debates of mainstream philosophy. Second, parts of his work were heavily loaded with formalization, restricting readership to specialists (e.g., the first four volumes of his Treatise). Third, the bigger his system grew over the years, the more difficult it became to communicate with the philosophical community. Bunge turned into some sort of prisoner of his own system, because it and thus his language deviated from mainstream use. Much of Bunge's terminology such as "scientific realism", "scientism", "determinism" and "cause" needs to be explicated before one can go on writing — unless one risks being misunderstood. Conversely, he occasionally misunderstood others. It is certainly interesting to compare Bunge's decidedly partisan "Philosophical Dictionary" (Bunge 2003b) with standard dictionaries.

Let us illustrate this situation with an example from the philosophy of mind, as we omitted this topic so far: the problem of mental causation. Bunge has "solved" this problem in that it simply is a non-problem in his philosophical system (Mahner 2015). But for others to see this, they would need to know and understand his metaphysics: his concepts of causation, event and property (in particular emergent property). In Bunge's metaphysics, only events are able to cause other events, whereby events are construed as changes of (material) things. For the mental to be able to cause something, it would have to be a thing of its own undergoing a change. This makes sense in dualism, yet not in materialism. So for Bunge there is no mind as an entity of its own but only mental properties of complex brains, emerging when specific neuronal systems undergo certain specific processes. This is a form of property epiphenomenalism (Bunge and Mahner 2004; Mahner 2015). Thus the relevant entity that is doing something is the neuronal system cum its emergent mental properties. Properties have no causal efficiency, whence mental properties have no "causal powers" either. No mental causation is needed as an interactive link between the mental and the neuronal, ${ }^{5}$ because there is only one entity (Bunge 1980; Bunge and Ardila 1987).

The philosophy of mind works on the basis of various fragments of ontological theories, but there is no generally accepted metaphysical theory. The concepts of cause, event and property mentioned above are all conceived of in different ways. Compare, for example, Yaegwon Kim's definition of "event" in contrast to Bunge's (Bunge 1977a; Kim 1993); or think of the often lax usage of "cause" as in John Searle's claim that the brain causes the mind (Searle 1997), which makes no sense in Bunge's ontology. While your peers may therefore not see the value of your approach, conversely the architect of a comprehensive philosophical system may tend to consider the engagement with views based only on metaphysical fragments as pointless and a waste of time.

Add to these factors a Latin temper, a big dose of impatience, and a lack of diplomacy $^{6}$ - three personality traits not exactly conducive to the job of a philosopher ${ }^{7}$ - said architect may also be tempted to frankly tell some of his peers that he considers their work as misguided or badly mistaken, in some cases even as unrecyclable garbage. Not the best

\footnotetext{
${ }^{5}$ More on property epiphenomenalism in Edelman et al. (2011) and Morgado-Bernal (2019). Baysan (2020) also discusses epiphenomenal emergence, although his ontological analysis would not have been approved by Bunge.

6 Bunge himself admitted in an interview that tact was not his strongest quality (Vacher 1993, 10).

7 For example, impatience may keep you from finding a more charitable interpretation of your peers' writings.
} 
way to make or keep friends! But not unprecedented either: recall Schopenhauer (1851) calling Hegel an ignorant charlatan and scribbler of nonsense. However, Bunge's occasional writing and talking cum ira et studio was not mean-spirited: it was an expression of frustration about what he regarded as a lack of progress in philosophy, caused by approaching philosophical problems in unsystematic ways. Furthermore, whenever he encountered philosophies that he regarded as having anti-scientific implications or as being downright irrationalist, he felt genuine moral outrage-and nobody could stop him from expressing it (see, e.g., Bunge 1996b). ${ }^{8}$ Of course, Bunge had no problem with acknowledging the work of other philosophers even if it was antithetical to his own. He just expected a certain level of systematicity and competence. For example, he was on good terms with Nicholas Rescher, whose comprehensive work he respected despite its idealist affinities.

In sum, Bunge was a very passionate and thereby polarizing philosopher. Those colleagues who took offense at his blunt criticism simply ignored his work. As a consequence, their students remained unfamiliar with it and likewise the following few generations of philosophers. Bunge's status as an enfant terrible of philosophy was such an open secret that, when in 1992 I applied for a post-doc stipend to work with him on the philosophy of biology, a well-known German philosopher considerately asked me during an interview whether I was aware of the problem that working with Bunge could be bad for my career.

Yet, in contrast to all hearsay, I did not meet a gruff person when I came to Montreal back then, but a supportive, trusting and liberal man who gave me free rein to organize our biophilosophy project; who let me stay in his house during a several month leave even though he had known me only for a short time; and who, despite his status and seniority, let me feature as the first author of the book that resulted from our collaboration, fairly acknowledging the distribution of the workload (Mahner and Bunge 1997). I found Bunge intimidating only in regard to his incredible memory and vast knowledge; indeed, he was a walking encyclopedia, a polymath, and a cosmopolitan able to converse in at least seven languages.

At the opposite pole, then, there are those who believe that Bunge's contributions not only to the philosophy of science but also to philosophy in general are sorely underrated, and who appreciate his philosophy for being systematic and comprehensive as well as clear and stimulating. In grander words: for being essentially a huge twentieth century Enlightenment project defending a realist and materialist outlook (Matthews 2019). I keep hearing stories, mostly from younger scientists and philosophers who came across his work, about how reading Bunge made "things fall into place" for them. It is probably these future generations who will rediscover Bunge's work by focusing on its content-disregarding the occasional furor philosophicus in its tone.

Acknowledgements I am indebted to Marta Bunge for checking the biography section, to Eric Bunge for kindly providing the photo, to Michael Matthews for valuable advice, and to Michael Kary for his close reading of the manuscript and helpful suggestions as well as the many discussions on Bunge's work we had over the past quarter century.

\section{References}

Austin, C. J. (2017). Aristotelian Essentialism. Essence in the Age of Evolution. Synthese, 194, 2539-2556. Baysan, U. (2020). Causal Emergence and Epiphenomenal Emergence. Erkenntnis, 85, 891-904. Blitz, D. (1992). Emergent Evolution. Qualitative Novelty and the Levels of Reality. Dordrecht: Kluwer.

8 This included some of his own colleagues from McGill's philosophy department (Bunge 2016). 
Bunge, M. (1944). A New Representation of Types of Nuclear Forces. Physical Review, 65, 249.

Bunge, M. (1945). Neutron-proton Scattering at 8.8 and $13 \mathrm{MeV}$. Nature, 156, 301.

Bunge, M. (1951). What is Chance? Science and Society, 15, 209-231.

Bunge, M. (1954). New Dialogues Between Hylas and Philonous. Philosophy and Phenomenological Research, 15, 192-199. [Reprinted in Mahner 2001.]

Bunge, M. (1955). Strife About Complementarity. British Journal for the Philosophy of Science, 6, 1-16 and 141-154.

Bunge, M. (1956a). A Survey of the Interpretations of Quantum Mechanics. American Journal of Physics, 24, 272-286.

Bunge, M. (1956b). Beitrag zur Diskussion über philosophische Fragen der modernen Physik. Deutsche Zeitschrift für Philosophie, 4, 467-496.

Bunge, M. (1957). Lagrangian Formulation and Mechanical Interpretation. American Journal of Physics, 25, 211-218.

Bunge, M. (1959). Causality: The Place of the Causal Principle in Modern Science. Cambridge, MA: Harvard University Press. [reissued in 1979 as Causality in Modern Science. New York: Dover Publications]

Bunge, M. (1960). La cinemática del electrón relativista. Tucumán: Universidad Nacional de Tucumán. Bunge, M. (1962). Intuition and Science. Englewood Cliffs, NJ: Prentice-Hall.

Bunge, M. (1963). The Myth of Simplicity. Englewood Cliffs, NJ: Prentice-Hall.

Bunge, M. (1964a). Phenomenological Theories. In M. Bunge (Ed.), The Critical Approach to Science and Philosophy (pp. 234-254). New York: Free Press.

Bunge, M. (Ed.). (1964b). The Critical Approach: Essays in Honor of Karl Popper. Glencoe, IL: Free Press. [New edition 1999 as Critical Approaches to Science and Philosophy. New Brunswick, NJ: Transaction Publishers].

Bunge, M. (1967a). Foundations of Physics. Berlin-Heidelberg: Springer-Verlag.

Bunge, M. (1967b). Scientific Research, 2 vols. Berlin-Heidelberg: Springer-Verlag.

Bunge, M. (1967c). A Ghost-Free Axiomatization of Quantum Mechanics. In M. Bunge (Ed.), Quantum Theory and Reality (pp. 105-117). Berlin-Heidelberg: Springer-Verlag.

Bunge, M. (1971). Is Scientific Metaphysics Possible? Journal of Philosophy, 68, 507-520.

Bunge, M. (1973a). Philosophy of Physics. Dordrecht: D. Reidel.

Bunge, M. (Ed.). (1973b). Exact Philosophy. Problems, Tools, and Goals. Dordrecht: D. Reidel.

Bunge, M. (1974a). Treatise on Basic Philosophy, Vol. 1-Semantics I: Sense and Reference. Dordrecht: D. Reidel.

Bunge, M. (1974b). Treatise on Basic Philosophy, Vol. 2-Semantics II: Interpretation and Truth. Dordrecht: D. Reidel.

Bunge, M. (1977a). Treatise on Basic Philosophy, Vol. 3-Ontology I: The Furniture of the World. Dordrecht: D. Reidel.

Bunge, M. (1977b). The Interpretation of Heisenberg's Inequalities. In H. Pfeiffer (Ed.), Denken und Umdenken. Zu Werk und Wirkung von Werner Heisenberg (pp. 146-156). München: Piper.

Bunge, M. (1977c). The Philosophical Richness of Technology. PSA 1976, 2, 153-172.

Bunge, M. (1979). Treatise on Basic Philosophy, Vol. 4 - Ontology II: A World of Systems. Dordrecht: D. Reidel.

Bunge, M. (1980). The Mind-Body Problem. Oxford, New York: Pergamon Press.

Bunge, M. (1981). Scientific Materialism. Dordrecht: D. Reidel.

Bunge, M. (1982a). Is Chemistry a Branch of Physics? Zeitschrift für Allgemeine Wissenschaftstheorie, 13, 209-223.

Bunge, M. (1982b). Demarcating Science from Pseudoscience. Fundamenta Scientiae, 3, 369-388.

Bunge, M. (1983a). Treatise on Basic Philosophy, Vol. 5 - Epistemology \& Methodology I: Exploring the World. Dordrecht: D. Reidel.

Bunge, M. (1983b). Treatise on Basic Philosophy, Vol. 6 - Epistemology \& Methodology I: Understanding the World. Dordrecht: D. Reidel.

Bunge, M. (1985a). Treatise on Basic Philosophy, Vol. 7 - Epistemology \& Methodology III: Philosophy of Science and Technology. Part I: Formal and Physical Sciences. Dordrecht: D. Reidel.

Bunge, M. (1985b). Treatise on Basic Philosophy, Vol. 7 - Epistemology \& Methodology III: Philosophy of Science and Technology. Part II: Life Science, Social Science and Technology. Dordrecht: D. Reidel.

Bunge, M. (1988). The Nature of Applied Science and Technology. In V. Cauchy (Ed.), Philosophie et Culture (pp. 599-605). Laval: Éditions Montmorency.

Bunge, M. (1989). Treatise on Basic Philosophy, Vol. 8 -Ethics: The Good and the Right. Dordrecht: D. Reidel. 
Bunge, M. (1991). A Critical Examination of the New Sociology of Science. Part 1. Philosophy of the Social Sciences, 21, 524-560.

Bunge, M. (1992). A Critical Examination of the New Sociology of Science. Part 2. Philosophy of the Social Sciences, 22, 46-76.

Bunge, M. (1993). Realism and Antirealism in Social Science. Theory and Decision, 35, 207-235.

Bunge, M. (1995). The Poverty of Rational Choice Theory. In I. C. Jarvie \& N. Laor (Eds.), Critical Rationalism, Metaphysics and Science. Essays for Joseph Agassi (Vol. I, pp. 149-168). Dordrecht: Kluwer.

Bunge, M. (1996a). Finding Philosophy in Social Science. New Haven CT: Yale University Press.

Bunge, M. (1996b). In Praise of Intolerance to Charlatanism in Academia. Annals of the New York Academy of Science, 775, 96-115.

Bunge, M. (1997). Mechanism and Explanation. Philosophy of the Social Sciences, 27, 410-465.

Bunge, M. (1998a). Social Science Under Debate. Toronto: University of Toronto Press.

Bunge, M. (1998a). The Philosophical Technologies. Technology in Society, 20, 377-384.

Bunge, M. (1999). The Sociology-Philosophy Connection. New Brunswick, NJ: Transaction Publishers.

Bunge, M. (2001). The Gap Between Mathematics and Reality. In M. Mahner (Ed.), Scientific RealismSelected Essays of Mario Bunge. Amherst, NY: Prometheus Books.

Bunge, M. (2003a). Emergence and Convergence. Toronto: University of Toronto Press.

Bunge, M. (2003b). Philosophical Dictionary. Amherst, NY: Prometheus Books.

Bunge, M. (2003c). Philosophy of Science and Technology: A Personal Report. In G. Fløistad (Ed.), Philosophy of Latin America (pp. 245-272). Dordrecht: Kluwer.

Bunge, M. (2006). Chasing Reality: The Strife over Realism. Toronto: University of Toronto Press.

Bunge, M. (2009). Political Philosophy: Fact, Fiction, and Vision. New Brunswick, NJ: Transaction Publishers.

Bunge, M. (2010). Matter and Mind. Dordrecht: Springer.

Bunge, M. (2012). Does Quantum Physics Refute Realism, Materialism and Determinism? Science and Education, 21, 1601-1610.

Bunge, M. (2013). Medical Philosophy. Conceptual Issues in Medicine. Singapore: World Scientific Publishing.

Bunge, M. (2015). Defense of Scientism. Free Inquiry, 35(1), 24-28.

Bunge, M. (2016). Between Two Worlds: Memoirs of a Philosopher-Scientist. Cham (CH): Springer Nature.

Bunge, M. (2017). Doing Science in the Light of Philosophy. Singapore: World Scientific Publishing.

Bunge, M. (2018a). From a Scientific Point of View. Newcastle, UK: Cambridge Scholars Publications.

Bunge, M. (2018b). Gravitational Waves and Spacetime. Foundations of Science, 23, 399-403.

Bunge, M., \& Ardila, R. (1987). Philosophy of Psychology. New York: Springer.

Bunge, M., \& Mahner, M. (2004). Über die Natur der Dinge. Materialismus und Wissenschaft. Stuttgart: Hirzel-Verlag.

Cordero, A. (2019). Mario Bunge's Scientific Approach to Realism. In M. R. Matthews (Ed.), Mario Bunge: A Centenary Festschrift (pp. 83-100). Cham (CH): Springer Nature.

Craver, C., \& Tabery, J. (2015). Mechanisms in Science. Retrieved July 18, 2020. plato.stanford.edu/entries/ science-mechanisms.

Dawes, G. W. (2018). Identifying Pseudoscience-A Social Process Criterion. Journal for General Philosophy of Science, 49, 283-298.

Edelman, G., Gally, J. A., \& Baars, B. J. (2011). Biology of Consciousness. Frontiers in Psychology, 2(4), 1-7.

Einstein, A., Podolsky, B., \& Rosen, N. (1935). Can Quantum-Mechanical Description of Reality be Considered Complete? Physical Review, 47, 777-780.

Ellis, B. (2002). The Philosophy of Nature. A Guide to the New Essentialism. Chesham, UK: Acumen.

Fernandez-Beanato, D. (2020). The Multicriterial Approach to the Problem of Demarcation. Journal for General Philosophy of Science, 51, 375-390.

Glennan, S. (2002). Rethinking Mechanistic Explanation. Philosophy of Science, 69(S3), S342-S353.

Hobson, A. (2019). A Realist Analysis of Six Controversial Quantum Issues. In M. R. Matthews (Ed.), Mario Bunge: A Centenary Festschrift (pp. 329-348). Cham (CH): Springer Nature.

Ingthorsson, R. D. (2019). Mario Bunge and the Current Revival of Causal Realism. In M. R. Matthews (Ed.), Mario Bunge: A Centenary Festschrift (pp. 205-217). Cham (CH): Springer Nature.

Johansson, I. (2019). Mechanism Models as Necessary Truths. In M. R. Matthews (Ed.), Mario Bunge: A Centenary Festschrift (pp. 241-262). Cham (CH): Springer Nature.

Kanitscheider, B. (2013). Natur und Zahl. Die Mathematisierbarkeit der Welt. Berlin: Springer-Spektrum.

Kim, J. (1978). Supervenience and Nomological Incommensurables. American Philosophical Quarterly, 15, 149-156. 
Kim, J. (1993). Supervenience and Mind. Cambridge, UK: Cambridge University Press.

Kistler, M. (2020). Introduction: New Trends in the Metaphysics of Science. Synthese, 197, 1841-1846.

Laudan, L. (1983). The Demise of the Demarcation Problem. In R. S. Cohen \& L. Laudan (Eds.), Physics, Philosophy, and Psychoanalysis (pp. 111-127). Dordrecht: D. Reidel.

Machamer, P., Darden, L., \& Craver, C. F. (2000). Thinking about Mechanisms. Philosophy of Science, 67, $1-25$.

Mahner, M. (2005). Mario Bunge's Philosophy of Biology. In Actas das XIII Xornadas de Filosofía Congreso-Homenaxe Internacional a Mario Bunge (pp. 103-139). Vigo: Grupo Aletheia.

Mahner, M. (2007). Demarcating Science from Non-Science. In T. A. F. Kuipers (Ed.), Handbook of the Philosophy of Science, Vol. 1: General Philosophy of Science - Focal Issues (pp. 515-575). Amsterdam: Elsevier.

Mahner, M. (2013). Science and Pseudoscience: How to Demarcate After the (Alleged) Demise of the Demarcation Problem? In M. Pigliucci \& M. Boudry (Eds.), Philosophy of Pseudoscience-Reconsidering the Demarcation Problem (pp. 29-43). Chicago: Chicago University Press.

Mahner, M. (2014). Science, Religion, and Naturalism: Metaphysical and Methodological Incompatibilities. In M. R. Matthews (Ed.), International Handbook of Research in History, Philosophy and Science Tteaching (Vol. III, pp. 1793-1835). Dordrecht: Springer-Verlag.

Mahner, M. (2015). The Philosophy of Mind Needs a Better Metaphysics. In S. Miller (Ed.), The Constitution of Phenomenal Consciousness: Toward a Science and Theory (pp. 293-309). Amsterdam: John Benjamins Publishing Company.

Mahner, M. (2018). Naturalismus-Die Metaphysik der Wissenschaft. Aschaffenburg: Alibri.

Mahner, M., \& Bunge, M. (1996). Is Religious Education Compatible with Science Education? Science and Education, 5, 101-123.

Mahner, M., \& Bunge, M. (1997). Foundations of Biophilosophy. Berlin-Heidelberg: Springer.

Matthews, M. R. (2019). Mario Bunge: An Introduction into His Life, Work, and Achievements. In M. R. Matthews (Ed.), Mario Bunge: A Centenary Festschrift (pp. 1-28). Cham (CH): Springer Nature.

McKinsey, J. C. C., Sugar, A. C., \& Suppes, P. (1953). Axiomatic Foundations of Classical Particle Mechanics. Journal of Rational Mechanics and Analysis, 2, 253-289.

Morgado-Bernal, I. (2019). Is Consciousness an Epiphenomenon? In M. R. Matthews (Ed.), Mario Bunge: A Centenary Festschrift (pp. 377-385). Cham (CH): Springer Nature.

Ortiz, E. L. (2019). Mario Bunge in the Complex Argentina of the 1940s-1960s. In M. R. Matthews (Ed.), Mario Bunge: A Centenary Festschrift (pp. 37-62). Cham (CH): Springer Nature.

Perez Bergliaffa, S. E., Romero, G. E., \& Vucetich, H. (1993). Axiomatic Foundations of Non-Relativistic Quantum Mechanics: A Realistic Approach. International Journal of Theoretical Physics, 32, $1507-1522$.

Pickel, A. (2004). Introduction: Systems and Mechanisms. A Symposium on Mario Bunge's Philosophy of Social Science. Philosophy of the Social Sciences, 34, 169-180.

Pigliucci, M., \& Boudry, M. (Eds.). (2013). Philosophy of Pseudoscience-Reconsidering the Demarcation Problem. Chicago: Chicago University Press.

Plenge, D. (2020). Big Problems Come in Bundles, Huge Nonsense Comes in Heaps, and Great Transformations Need Sound Philosophical Foundations. A Note on Mario A. Bunge (1919-2020) and the Future of Philosophy of History and Social Science. Retrived Aug 2, 2020 https://www.oulu. fi/blogs/bunge

Popper, K. R. (1969). Logik der Forschung. Tübingen: Mohr-Siebeck.

Railton, P. (1978). A Deductive-Nomological Model of Probabilistic Explanation. Philosophy of Science, 45, 206-226.

Romer, R. H. (1991). Editorial: Memorable Papers from the American Journal of Physics, 1933-1990. American Journal of Physics, 59, 201-207.

Romero, G. E. (2019). Physics and Philosophy of Physics in the Work of Mario Bunge. In M. R. Matthews (Ed.), Mario Bunge: A Centenary Festschrift (pp. 289-301). Cham (CH): Springer Nature.

Salmon, W. (1984). Scientific Explanation and the Causal Structure of the World. Princeton: Princeton University Press.

Salmon, W. (1989). Four Decades of Scientific Explanation. Minneapolis: University of Minnesota Press.

Schlosshauer, M., Kofler, J., \& Zeilinger, A. (2013). A Snapshot of Foundational Attitudes Toward Quantum Mechanics. Studies in History and Philosophy of Modern Physics, 44, 222-230.

Schopenhauer, A. (1851). Parerga und Paralipomena (Vol. 1). Berlin: Hahn.

Searle, J. (1997). The Mystery of Consciousness. New York: New York Review of Books.

Sneed, J. D. (1979). The Logical Structure of Mathematical Physics. Dordrecht: Reidel.

Stegmüller, W. (1976). The Structure and Dynamics of Theories. New York: Springer. 
Stenger, V. J. (1995). The Unconscious Quantum. Metaphysics in Modern Physics and Cosmology. Amherst, NY: Prometheus Books.

Stöckler, M. (1990). Realism and Classicism, or Something More? Some Comments on Mario Bunge's Philosophy of Quantum Mechanics. In P. Weingartner \& G. J. W. Dorn (Eds.), Studies on Mario Bunge's Treatise (pp. 351-363). Amsterdam: Rodopi.

Suppe, F. (1972). What's Wrong with the Received View of the Structure of Scientific Theories. Philosophy of Science, 39, 1-19.

Suppe, F. (1989). The Semantic Conception of Theories and Scientific Realism. Urbana, IL: University of Illinois Press.

Suppes, P. (1957). Introduction to Logic. New York: Van Nostrand Reinhold.

Tahko, T. E. (Ed.). (2012). Contemporary Aristotelian Metaphysics. Cambridge, UK: Cambridge University Press.

Thompson, P. (1989). The Structure of Biological Theories. Albany, NY: SUNY Press.

Truesdell, C. (1984). An Idiot's Fugitive Essays on Science. Berlin: Springer.

Vacher, L.-M. (Ed.). (1993). Entretiens avec Mario Bunge. Une philosophie pour l'âge de la science. Montreal: Editions Liber.

Weingartner, P. (1990). The Non-Statement View. A Dialogue between Socrates and Theaetetus. In P. Weingartner \& G. J. W. Dorn (Eds.), Studies on Mario Bunge's Treatise (pp. 455-465). Amsterdam: Rodopi.

\section{Bibliographies of Mario Bunge and Festschrift Volumes}

Agassi, J., \& Cohen, R. S. (Eds.). (1982). Scientific Philosophy Today: Essays in Honor of Mario Bunge. Dordrecht: D. Reidel.

Blitz, D., et al. (1990). Bibliography of Mario Bunge's Publications, 1939-1989. In P. Weingartner (Ed.), Studies on Mario Bunge's Treatise (pp. 685-708). Amsterdam: Rodopi.

Denegri, G. (Ed.). (2014). Elogio de la sabiduría. Ensayos en homenaje a Mario Bunge en su $95^{\circ}$ aniversario. Buenos Aires: Eudeba.

Denegri, G. M., \& Martinez, G. (Eds.). (2000). Tópicos actuales en filosofía de la ciencia. Homenaje a Mario Bunge en su $80^{\circ}$ Aniversario. Editorial Martín: Universidad Nacional de Mar del Plata.

Grupo Aletheia (Ed.). (2005). Congreso-Homenaxe Internacional a Mario Bunge. Pontevedra: Grupo Aletheia.

Mahner, M. (Ed.). (2001). Scientific Realism-Selected Essays of Mario Bunge. Amherst, NY: Prometheus Books.

Matthews, M. R. (Ed.). (2019). Mario Bunge: A Centenary Festschrift. Cham (CH): Springer Nature.

Plenge, D. (2019). ArchivoDigital MarioBunge. Retrieved Sept 202020 www.youtube.com/channel/UCz7f AQeVZVGTBca4BO2Kpmg

Silberstein, M. (2019). Mario Bunge Publications (All Languages). In M. Matthews (Ed.), Mario Bunge: A Centenary Festschrift (pp. 775-807). Cham (CH): Springer Nature.

Weingartner, P., \& Dorn, G. J. W. (Eds.). (1990). Studies on Mario Bunge's Treatise. Amsterdam: Rodopi.

Publisher's Note Springer Nature remains neutral with regard to jurisdictional claims in published maps and institutional affiliations. 